\title{
EFFECT OF PRECEDING CROP AND NITROGEN RATE ON GRAIN YIELD AND YIELD COMPONENTS OF MAIZE (ZEA MAYS L.)
}

\author{
Sheha, A. M. ,M.k, Hamdan ${ }^{1}$ A.M. Abou-Elela1, and N. I. Abd \\ Elkader ${ }^{2}$ \\ 1-Crops Intensification Dept .Agric.Res.Center, Giza,Egypt. 2- Soil \\ and Water Science Fac. of Agric., Tanta Univ., Egypt
}

\begin{abstract}
The experiment was conducted at the Experimental Farm of El Gemmeiza, Agricultural Research Station, El-Gharbia Governorate, Egypt, during $2012 / 2013$ and 2013/2014 growing seasons. The experimental design was strip plot with three replications. Main plots were devoted to preceding crops, faba bean, sugar beet and wheat .Maize cultivar S.C. 128 was grown after three winter crops. While nitrogen fertilizer rates $(60,75,90$ and $105 \mathrm{~kg} \mathrm{~N}$ /fed) were allocater sup plots. Results showed that All characters of maize were significantly affected by preceding winter crops and nitrogen levels in both seasons. Results indicated that preceding crops significantly affect on maize yield. The highest yield (18.41 and18.10 ardab/fed) in both seasons ,res, and yield components were obtained after faba bean as preseding crop and $105 \mathrm{kgN} / \mathrm{fed}$. Whereas, the lower yield of maize (14.46 and 14.95) were obtained after wheat as preseding crop and $60 \mathrm{~kg} \mathrm{~N} / \mathrm{fed}$. In both seasons, The interaction between preceding crop $\mathrm{x}$ nitrogen rates not significant on all traits of maize crop in both seasons. The highest values of cereal units were observed by sugar beet as preceding crop. Generally, it can be concluded that fertilizing with $105 \% \mathrm{~kg} \mathrm{~N} / \mathrm{fed}$ with faba bean as preceding crop to maize may be to improve the productivity of maize crop under the conditions of the present study .
\end{abstract}

Key words: Preceding crop, Nitrogen rate, Maize Yield and Yield components.

\section{Introduction}

Maize (Zea mays, L.) is the world's widely grown highland cereal and primary staple food crop in many developing countries. It is the third most important staple food crop both in terms of area and production after wheat and rice in Egypt. Total area under cultivation of maize in Egypt is 888329 hacter which is about $25.17 \%$ of the total cultivated agricultural land while average yield is $7.80 \mathrm{ton} / \mathrm{ha}$. It is about $21.90 \%$ of the total cereals production (FAO, 2011). Maize is used as a food for human diet, feed poultry and animals. It is used as raw materials for preparation of starch, corn, dextrose, corn syrup and 
corn flakes industries (Khaliq et al.(2004) .Maize ranks 3rd in world's cereals crops after wheat and rice as food crop (Chaudary, 1994). The main objective now in Egypt is to increase the production of grain crops, maintain soil fertility. reduce environmental pollution and the rotation is done planting Preceding winter crops as first crops with summer grain crops maize as second crops that suit climatic and environmental conditions in Egypt, it uses light effectively and has the ability to produce a large amount of dry matter in a short time so farmers prefer to use maize as a second crop with the Preceding winter crops (Cesurer, 1995). When nitrogen is deficient in the soil, then addition of $\mathrm{N}$ fertilizer from outer source increased the grain yield of maize (Wienhold et al., 1995). Using waste and remnants of previous crops to improve the natural qualities. biological and chemical characteristics of the soil and thus increase the production of the next crop (Calderon, 2000) Some researchers demonstrated the benefits of crop rotation compared to a monoculture of maize, such as higher yield when cereals follow a legume as this saves nitrogen and breaks the disease cycle of grains. Nitrogen is the key element in increasing grain yield and quality of maize. In recent years emphasis has been given to increase fertilizers use efficiency by top dressing and split applications of nitrogenous fertilizers at critical growth stages of maize (Singh, 1985). Application of $\mathrm{N}$ increases soil fertility and crop productivity. About $43-68 \%$ increase in yield and $25-42 \%$ increase in biomass were observed with the addition of nitrogen fertilizer (Ogola et al., 2002).. Some researchers demonstrated the benefits of crop rotation compared to a monoculture of maize. Planting second crops a big need for rotation between leguminous plants and cereal plants because it contributes to increase soil fertility and increase crop production (Leyla and Sevim, 2011). Kamran et al. (2014) suggested that addition of $\mathrm{N}$ and appropriate nitrogen level affect yield and yield components of maize considerably. Nitrogen sources and nitrogen levels significantly affect the agronomic performance of maize.

Khan et al. (2012) showed that increase of nitrogen levels enhanced final seed yield due to increase of seed number in each ear, also, nitrogen levels had, significantly affected the maize plant height and the tallest plants were recorded under 120 and $150 \mathrm{~kg} /$ ha $\mathrm{N}$ levels and the greatest grain yield of maize (1.5 t/ ha) was found under the $160 \mathrm{~kg} / \mathrm{ha} \mathrm{N}$ level

The objectives of this research were to evaluate the effects of preceding winter crops (i.e., faba bean, sugar beet and wheat) as previous crops and $\mathrm{N}$ fertilization rates on maize yield and yield components. 


\section{Materials and Methods}

Field experiments were carried out in a clay soil at the Experimental Farm of El- Gemmeiza Agricultural Research Station, El-Gharbia Governorate, during two growing seasons 2012 -2013 and 2013-2014, to study the effect of three preceding winter crops and four nitrogen fertilizer rates on maize(cultivar S.C. 128 ) as a summer crop. The experimental design was strip-plots design with three replication, where the preceding winter crops were faba bean (Sakha $11 \mathrm{cv}$.), sugar beet (Beta ploy cv.) and wheat (Gemmeiza 11 $\mathrm{cv}$. allotted to main plot, while nitrogen levels ( $60 \mathrm{~kg} / \mathrm{fed}, 75 \mathrm{~kg} / \mathrm{fed}, 90$ $\mathrm{kg} / \mathrm{fed}$ and $105 \mathrm{kgN} / \mathrm{fed}$ ) were allotted to the sub plot. Each sub-plot was $19.60 \mathrm{~m}^{2}$ in area, consisting of 8 ridges (each, $3.5 \mathrm{~m}$ long and 0.7 $\mathrm{m}$ wide for ridges) of presiding crop. Data for the site climatic conditions were taken from El-Gharbia meteorological station according to the formal data from the ministry of agriculture during the two growing seasons are presented in table (1).

Table (1): The average of temperature and relative humidity in $2012-2013$ and 2013-2014seasons and physicochemical of the experiments soil

\begin{tabular}{|c|c|c|c|c|}
\hline \multirow[b]{2}{*}{ Month } & \multicolumn{2}{|c|}{ First season2012-2013 } & \multicolumn{2}{|c|}{ Second season2013-2014 } \\
\hline & $\begin{array}{l}\text { Temperature } \\
{ }^{(0} \mathrm{C} \text { ) }\end{array}$ & $\begin{array}{l}\text { Relative } \\
\text { humidity( \%) }\end{array}$ & 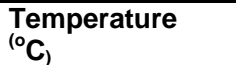 & $\begin{array}{l}\text { Relative } \\
\text { humidity (\%) }\end{array}$ \\
\hline May & 28.46 & 61.35 & 27.66 & 63.62 \\
\hline June & 29.45 & 68.1 & 28.56 & 66.48 \\
\hline July & 31.84 & 71.06 & 30.91 & 70.89 \\
\hline August & 32.52 & 69.75 & 33.71 & 71.57 \\
\hline Sept & 26.58 & 66.25 & 26.88 & 68.53 \\
\hline
\end{tabular}

Table 2:

\begin{tabular}{|c|c|c|c|c|}
\hline \multirow{2}{*}{ Determination Mechanical } & \multicolumn{2}{|c|}{ First season 2012/2013 } & \multicolumn{2}{|c|}{ Second season 2013/2014 } \\
\hline & $0-30$ & $30-60$ & $0-30$ & $30-60$ \\
\hline Clay \% & 57.24 & 55,21 & 55.47 & 54.00 \\
\hline Silt \% & 22.29 & 21.94 & 23.68 & 22.80 \\
\hline Sand $\%$ & 20.57 & 22.85 & 20.85 & 23.20 \\
\hline Texture & \multicolumn{4}{|c|}{ Clay } \\
\hline Chemical analysis: & & & & \\
\hline Available N (ppm) & 22.9 & 21.8 & 24.0 & 22.0 \\
\hline Available $\mathrm{P}_{2} \mathrm{O}_{5}(\mathrm{ppm})$ & 9.0 & 8.5 & 11.0 & 10.0 \\
\hline Available $\mathrm{K}_{2} \mathrm{O}(\mathrm{ppm})$ & 350 & 335 & 360 & 400 \\
\hline $\mathrm{Ec}\left(\mathrm{mmhos} / \mathrm{cm}^{3}\right)$ & 0.8 & 0.8 & 0.9 & 0.9 \\
\hline & 7.40 & 7.3 & 7.3 & 7.2 \\
\hline $\mathrm{CaCo}_{3} \%$ & 2.71 & 3.10 & 3.0 & 3.0 \\
\hline Organic matter \% & 1.0 & 1.1 & 1.2 & 1.2 \\
\hline \multicolumn{5}{|l|}{ Cations (meq/100 g.soil) } \\
\hline $\mathrm{Na}^{+}$ & 0.36 & 0.37 & 0.37 & 0.37 \\
\hline $\mathrm{K}^{+}$ & 0.01 & 0.01 & 0.03 & 0.04 \\
\hline $\mathrm{Ca}^{++}$ & 0.25 & 0.27 & 0.24 & 0.24 \\
\hline $\mathrm{Mg}^{++}$ & 0.26 & 0.28 & 0.22 & 0.22 \\
\hline \multicolumn{5}{|l|}{ Anions (meq/100 g. soil) } \\
\hline 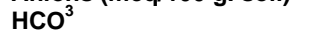 & 0.32 & 0.48 & 0.36 & 0.40 \\
\hline & 0.38 & 0.39 & 0.28 & 0.30 \\
\hline $\mathrm{SO}_{4}$ & 0.20 & 0.06 & 0.22 & 0.12 \\
\hline
\end{tabular}


Faba bean was sown on the upper and one side of ridges in hills(2 plants /hill)spaced at $20 \mathrm{~cm}$. sugar beet was sown on side of ridges in hills (one plant/hill) at a distance of $20 \mathrm{~cm}$ between hills. While wheat were sown in two rows on the top of ridges according to the recommendations for optimal plant density.Maize was sown on one side of ridge in hills (one plant/hill) at $25 \mathrm{~cm}$ among plants. Preceding crops and maize sowing and harvesting dates are presented in Table (3).

Nitrogen,as ammonium nitrate(33.5\% N)was added to maize in two equal doses, at the first and second irrigation. All other cultural practices were uniformaly applied according to recommendations.

Table 3 : Planting and harvesting dates of preceding crop and summer crop in 2012/2013 and2013/2014 seasons

\begin{tabular}{|l|l|l|l|l|}
\hline \multirow{2}{*}{ Crop } & \multicolumn{2}{|l|}{ First season (2012 / 2013) } & \multicolumn{2}{|l|}{ Second season $(\mathbf{2 0 1 3} / \mathbf{2 0 1 4})$} \\
\cline { 2 - 5 } & $\begin{array}{l}\text { Planting } \\
\text { date }\end{array}$ & $\begin{array}{l}\text { Harvesting } \\
\text { date }\end{array}$ & $\begin{array}{l}\text { Planting } \\
\text { date }\end{array}$ & $\begin{array}{l}\text { Harvesting } \\
\text { date }\end{array}$ \\
\hline $\begin{array}{l}\text { Faba } \\
\text { bean(A1) }\end{array}$ & $15 / 10 / 2012$ & $20 / 4 / 2013$ & $18 / 10 / 2013$ & $23 / 4 / 2014$ \\
\hline $\begin{array}{l}\text { Sugar } \\
\text { beet(A2) }\end{array}$ & $15 / 10 / 2012$ & $9 / 5 / 2013$ & $18 / 10 / 2013$ & $12 / 5 / 2014$ \\
\hline Wheat(A3) & $15 / 11 / 2012$ & $3 / 5 / 2013$ & $25 / 11 / 2013$ & $9 / 5 / 2014$ \\
\hline Maize & $15 / 05 / 2013$ & $15 / 9 / 2013$ & $18 / 05 / 2014$ & $15 / 9 / 2014$ \\
\hline
\end{tabular}

Table 4: The average yield of preceding winter crops in both seasons

\begin{tabular}{|c|c|c|c|c|c|c|c|c|}
\hline Crop & $\begin{array}{c}\text { Root } \\
\text { (t./fed) }\end{array}$ & $\begin{array}{c}\text { Top } \\
\text { (t./fed) }\end{array}$ & $\begin{array}{c}\text { Seed yield } \\
\text { (ardab/fed) }\end{array}$ & $\begin{array}{c}\text { Straw } \\
\text { yield(kg/fed) }\end{array}$ & $\begin{array}{c}\text { Root } \\
\text { (t./fed) }\end{array}$ & Top (t./fed) & $\begin{array}{c}\text { Seed yield } \\
\text { (ardab./fed) }\end{array}$ & $\begin{array}{c}\text { Straw yield } \\
\text { (kg/fed) }\end{array}$ \\
\hline $\begin{array}{c}\text {. Faba } \\
\text { bean }\end{array}$ & $\ldots \ldots$. & $\ldots \ldots \ldots$ & 10.48 & 1100 & $\ldots \ldots$ & $\ldots \ldots \ldots$ & 9.85 & 988 \\
\hline $\begin{array}{c}\text { sugar } \\
\text { beet }\end{array}$ & 24.63 & 12.89 & $\ldots \ldots \ldots$ & $\ldots \ldots \ldots$ & 26.17 & 12.75 & $\ldots \ldots \ldots$ & $\ldots \ldots \ldots$ \\
\hline Wheat & & & 21.25 & 1350 & & & 20.65 & 1250 \\
\hline
\end{tabular}

\section{Field sampling and data collection}

At harvest time, a sample of 10 plants was randomly collected from each sub plot to measure. -Maize yield and its components

1- Plant height $(\mathrm{cm})$ 2-Ear height 3- Ear lengh 4-Eardiameter

5-Number of grains/ ear 6- 100- grain weight (g). 7- Ear grain weight(g) 8- Leaf area index

$$
\text { 9-Grain yield (ardab/fed.)..- }(\operatorname{ardab}=140 \mathrm{~kg})
$$

Plant height: Plant heights $(\mathrm{cm})$ of five randomly selected plants were measured from the ground level to the top of tassel in each sub plot and then their means were calculated.

Leaf area indexes (LAI) :were recorded. Leaf area was measured according to the method described by Radford (1967) according to the 
equation, $L A=K(L x B)$, where: $\quad L A=$ leaf area $\left(\mathrm{cm}^{2}\right), \quad K=$ constant (0.75), $L=$ leaf length $(\mathrm{cm}), B=$ maximum leaf width $(\mathrm{cm})$ and $L A l=$ $\mathrm{LA} / \mathrm{GA}$; where $\mathrm{GA}=$ ground area which occupied by plant.

\section{0- grains weight (g)}

A random sample of thousand grains were taken from the grain yield of each sub plot and weighed with an electronic balance to record weight for 100 - grains.

\section{Number of grains/ ear}

To record the number of grains /ear, grains of ten randomly selected ears in each plot were counted and then averaged.

\section{Grain yield (ardab/fed)}

For recording grain yield data, three central rows were harvested in each sub plot with the help of a sickle. Ears were removed from the harvested plants, dried threshed and weighed with the help of an electronic balance and the data will then be converted in to ardab /fed.

\section{Cereal unit:}

The yield of all crops were changed to units of cereal according by Brockaus(1962)for judicious comparison between 100kg for each crops as follow:maize $=1$ unit,faba bean $=1.20$ units, sugar beet $=0.25$ unit, wheat $=1$ unit , straw yield for fababean $=0.25$ unit, straw yield for wheat $=0.15$ unit, maize $=0.15$ unit and Top yield for sugar beet $=0.10$ unit.

Table (5): Cereal units to preceding crops and maize of both season

\begin{tabular}{|c|c|c|c|c|}
\hline Preceding crops & Cropping system & \multicolumn{2}{|c|}{ Cereal units } & \\
\hline & & First season & Second season & Mean \\
\hline Faba bean & Maize + faba bean & 60.35 & 61.94 & 61.14 \\
\hline Sugar beet & Maize + sugar beet & 116.55 & 104.06 & 110.30 \\
\hline Wheat & Maize + wheat & 70.68 & 69.24 & 69.96 \\
\hline
\end{tabular}

\section{Statistical analysis:}

Data statistically analyzed as the technique analysis of variance (ANOVA) of strip- plot design as mentioned by Gomez and Gomez (1984). Treatment means were compared using the Least Significant Difference (LSD at 5\%) test as outlined by Waller and Duncan (1969).

\section{Results and discussion}

Effect of preceding winter crops on maize yield and its components

Data in Tables (6 and 7) indicate significant effect for preceding crop on ,plant height, ear length, ear height, ear diameter, 100 grains weight, number of grains/ear, grain yield/plant, leaf area index and 
grain yield / fed in 2013/2013 and2013/2014 seasons , as well as number of rows / ear only in the second season .

Mean value of Table (6) show that plant height, ear height, ear length, ear diameter of maize plants were significantly affected by preceding crops. Data indicated that maize plants after faba bean produced the highest values of these characters in plants were( plant height250.91, 249.91(ear height,140.08,139.25), (ear length 20.45, 20.42) and (ear diameter 47.85,47.75)after faba bean in both seasons respectively ,compared to maize plants after the two other preceding winter crops. These might be attributed to the more availability of $\mathrm{N}$ and less $\mathrm{N}$ uptake as faba bean the preceding crop. Consequently, maize did uptake greater $\mathrm{N}$ amount and had taller plants (Nawar, 2004 and Khalil et al., 2011). The increases in these characters after faba bean compared to that after sugar beat and wheat plants might be attributed to the higher soil organic matter and $\mathrm{N}$ content that largely enhanced the maize vegetative growth in terms of plant height and other characters(El-Sdodany and Abou-Elela, 2010 and Khalil et al.2011.

Also, data in table (6) indicated that 100-grain weight and number of grains /ear was influenced significantly by preceding crops . The highest 100-grain weight (31.72 and31.57) and number of grains/ear(552.50 and549.80),were obtained when maize planting after faba bean compared sugar beet and wheat in both seasons, respectively . Increasing soil organic $\mathrm{N}$ and carrying over of $\mathrm{N}$ from faba bean residues to the subsequent maize might be responsible for such increase in grain number/ear. Physiologically, the greater $\mathrm{N}$ uptake of maize plants after faba bean increased photosynthetic rate and photo assimilates translocation to ear , which caused the number of grains /ear and the other characters to be higher for maize ear after faba bean than did after the other preceding crops(Rizvi and Rizvi,1992, Khalil et al. 2011 and Abou-Keriasha and Nadia Eissa (2014).

Mean value of Table (7) shows that weight of grains/ear, leaf area index and grain yield (ardab/fed.) was significantly affected by preceding crops. Among the preceding crops plots grown with faba bean had higher weight of grains /ear (174.35 and174.29), leaf area index(5.21 and5.18) and grain yield (22.98 and $22.87 \mathrm{ardab} / \mathrm{fed})$ in first and second seasons, respectively. Faba bean was superior to both sugar beet and wheat regarding all studied characters of maize. That was in an agreement with the results of Nawar (2004), Khalil et al.(2011) and Arif et al., ( 2011 found that leguminous crops caused maize to produce higher values of grain yield attributes such as number of grains/ear ear grain weight and grain yield /fed .In addition, 
Drinkwater et al. (2000) observed that legume based cropping patterns increase the organic matter content consequently result in sustainable yields of crops. Ali et al(2015) reported that This increase might be due to the liter and leaf biomass on the soil in leguminous crops plots. The leaf biomass is of high quality, it decompose more rapidly and supply more nitrogen.

\section{Effect of Nitrogen rates on maize yield and its components}

Data of analysis of Table(6 and7) indicated that plant height , ear length , ear height, ear diameter ,100 grains weight , number of grains/ear grain yield /plant, leaf area index and grain yield / fed were significantly responded to the effect of the nitrogen rates in both seasons.

Data presented in Table( 6 )shows that plant height, ear height, ear length and ear diameter,100-grains weight and number of grains /ear of maize plants were significantly affected by nitrogen $(\mathrm{N})$ fertilizer rates in both seasons. The plant height and other characters significantly increased with increase in N from 60 to $105 \mathrm{~kg} \mathrm{~N} /$ fed.. Data indicated that maize plants produced the highest values of these characters in plants were( plant height261.12, 260. $49 \mathrm{~cm})($ ear height, $, 140.08,139.25 \mathrm{~cm}$ ), ( ear length $22.10,21.80 \mathrm{~cm}$ ), (ear diameter $48.98,48.89 \mathrm{~mm}$ ) (100-grains weight :33.27 and $33.14 \mathrm{~g}$ ) and (number of grains /ear :604.0 and 598.0)with $105 \mathrm{kgN} / \mathrm{fed}$ in both seasons, respectively. The increment in plant height and other characters with the rise in $\mathrm{N}$ dose indicated that plants used $\mathrm{N}$ during active cell division to form building blocks (protein) for cell elongation. The performance of maize plant might be the result of residual soil fertility improved. These results are in line with those of Balasbramaniyan and Palaniappan (2001). The data pertaining to 100-grains weight and number of grains/ear influenced by nitrogen are presented in table (6 ). It is revealed from the data that nitrogen rates had significant effects on these characters in both seasons. The highest values of 100 -grain weight 33.27 and33.14 ) and number of grains/ear(604.0 and598.0)were recorded from $105 \mathrm{~kg} \mathrm{~N} / \mathrm{fed}$ in the first and second seasons, respectively. The more number of grains/ ear might be due to more photo-assimilates production translocation into ears in leguminous crops, hence increased both number of fertile grains/ear and individual grain weight (Wallach, 1995 , and Ali et al(2015. Whereas, Muhammad and Khan Saeed (2005) and khalil et al ,2011), they reported that yield contributing characters such as thousand grain weight, number of grains/ ear with higher doses of inorganic fertilizer in combination with manure resulting in higher yield.

Mean value of Table (7) shows that weight of grains/ear, leaf area index and grain yield /fed.were significantly affected by nitrogen 
(N) applied. The grain weight and other characters slightly increased with increasing in nitrogen application from 60 to $105 \mathrm{~kg} / \mathrm{fed}$. Weight of grains/ear, leaf area index and grain yield were observed to be higher in the plots where nitrogen was applied at the rate of $105 \mathrm{~kg} \mathrm{~N}$ /fed (184.12and183.59),(5.99 and5.98 and(24.22 and 24.09)in the first and second seasons, respectively . whereas the lower grain yield was noted at rate $60 \mathrm{~kg} \mathrm{~N} / \mathrm{fed}(16.99$ and 16.91)in both seasons, respectively . Gardener et al.,1985 found that the increase in N supply and greater $\mathrm{N}$ uptake by maize might have increased the leaf length and width dimensions, leading to increases in leaf eare. The increase in grain yield was probably might be due to the more number of grains/row, number of row/ear and 100-grain weight. These results are supported by the finding of Muhammad and Khan Saeed (2005) and Khalil et al.2011. Plant as well as plant height is an important yield component as more green area more will be share to grain yield.

\section{Effect of interaction between preceding crop and nitrogen levels on maize :}

Results indicate that the interaction between preceding crop and $\mathrm{N}$-level had no significant effect on all studied traits of maize plants in both seasons, Table (6 and7).

\section{Effect of preceding crop and nitrogen fertilizer on cereal unitsl}

Data presented in table (5) show that the average of cereal unit varied by different of preceding crops and nitrogen fertilizer. The results indicated that the sugar beet as preceding crop gave the highest values of cereal units (116.55 and 104.06) in the first and second seasons, respectively. While the lowest values was observed with faba bean (60.35 and 61.94) in both seasons, respectively. The results are in agreement with those of Abou-Keriassha and Eissa (2014).

\section{Available N, P and $\mathrm{K}$ after maize harvested}

Data presented in Table (8) show the effect of preceding winter crop and nitrogen fertilizer rate on $\mathrm{N}, \mathrm{P}$ and $\mathrm{K}$ availability in soil after maize harvesting and show that sowing faba been gave the highest mean values of soil available $\mathrm{N}, \mathrm{P}$ and $\mathrm{K}$ in soil where they reached 39.07 and $36.84 \mathrm{ppm}$ for available $\mathrm{N}, 13.95$ and $13.31 \mathrm{ppm}$ for available $P$ and 409.10 and 407.40 ppm for available $K$ at the end of the first and second years respectively. Wheat as preceding winter crop gave the lowest mean values of available $\mathrm{N}$, which reached to 36.50 to $34.48 \mathrm{ppm}$ for available $\mathrm{N} ; 12.75$ and $12.1 \mathrm{ppm}$ for available $\mathrm{P}$ and 399.4 and $397.4 \mathrm{ppm}$ for available $\mathrm{K}$ at the end of the first and second season, respectively. These results revealed that faba been, as a preceding winter crop enriched the soil with $\mathrm{N}, \mathrm{P}$ and $\mathrm{K}$ and its 
residues had beneficial effects on improving soil chemical properties (Farghly, 2001). Similar results was obtained by El-Sodany and Abou-Elela, (2010) ,Who reported that, the preceding winter crops had a significant effect on soil nutrient changes and increasing $\mathrm{N}, \mathrm{P}$ and $\mathrm{K}$ status of the soil.

Also, data in Table (8) show that increasing nitrogen fertilizer rate from 60 to $105 \mathrm{~kg} \mathrm{~N} /$ fed. significantly increased soil available from $\mathrm{N}, \mathrm{P}$ and $\mathrm{K}$ in the two seasons. The mean values of available $\mathrm{N}$, $\mathrm{P}$ and $\mathrm{K}$ ranged from 25.18 to $32.22,22.10$ to $30.62 \mathrm{ppm}$ for available $\mathrm{N}$; from 11.23 to 14.08 to 10.81 to $12.92 \mathrm{ppm}$ for available $\mathrm{P}$ and from 288.4 to $344.3 ; 286.4$ to $342.2 \mathrm{ppm}$ for available $\mathrm{K}$ in the first and second seasons respectively. In general, results show that available $\mathrm{N}$, $\mathrm{P}$ and $\mathrm{K}$ were increased with increasing nitrogen fertilizer rate and macronutrients were high in the first years compared to the second years. These results are agreement with obtained with Sodany and Abou-Elela, (2010). This may be due to that the higher nitrogen level led to slightly change in soil $\mathrm{pH}$ and/ or increased cation exchange which ,led to increased $\mathrm{K}$ released.

Data presented in Table (9) show the interaction effect between the preceding winter crop and nitrogen fertilizer rate on $\mathrm{N}, \mathrm{P}$ and $\mathrm{K}$ availability in soil after maize harvesting and show that, sowing faba been as preceding crop and adding $105 \mathrm{kgN} / \mathrm{fed}$. for maize plants gave the highest mean values of soil available from $\mathrm{N}, \mathrm{P}$ and $\mathrm{K}$, where they reached to 38.48 and $36.59 \mathrm{ppm}$ for available $\mathrm{N}, 13.01$ and $12.59 \mathrm{ppm}$ for available $\mathrm{P}$ and 407.5 and $406.4 \mathrm{ppm}$ for available $\mathrm{K}$ at the end of the first and second seasons respectively. But growing maize plants after wheat with $60 \mathrm{~kg} \mathrm{~N} / \mathrm{fed}$ recorded the lowest mean values of available $\mathrm{N}$, which reached to 30.62 to $28.45 \mathrm{ppm}$ for available N, 10.62 and 10.27 ppm for available $P$ and 327.7 and 326.1 ppm for available $K$ at the end of the first and second years respectively. These results revealed that the interaction effect between faba been as a preceding winter crop with the different rates of $\mathrm{N}$ enriched the soil with $\mathrm{N}, \mathrm{P}$ and $\mathrm{K}$ compared to the two other winter crops.

\section{Conclusion}

It can be concluded that faba bean as preceding winter crop with $105 \mathrm{~kg} \mathrm{~N} / \mathrm{fed}$ for maize plants was the best combination to nmaximizing grain yield of maize and its components as well as soil fertility under the same agro-climatic conditions of thes research at the Experimental Farm of El Gemmeiza Agricultural Research Station, ElGharbia Governorate . 
Table (6) Means of plant height $(\mathrm{cm})$, ear height $(\mathrm{cm})$, ear length $(\mathrm{cm})$, ear diameter(mm), 100-grain weight and Number of grains/ear of maize as affected by different preceding crops and $\mathrm{N}$ levels during 2013 and 2014 seasons.

\begin{tabular}{|c|c|c|c|c|c|c|c|c|c|c|c|c|}
\hline \multirow[t]{2}{*}{ Treatment } & \multicolumn{2}{|c|}{ plant height(cm) } & \multicolumn{2}{|c|}{ Ear height } & \multicolumn{2}{|c|}{ Ear length } & \multicolumn{2}{|c|}{ Ear diameter } & \multicolumn{2}{|c|}{ 100-grain weight(g)) } & \multicolumn{2}{|c|}{$\begin{array}{l}\text { Number of } \\
\text { grains/ear }\end{array}$} \\
\hline & 2013 & 2014 & 2013 & 2014 & 2013 & 2014 & 2013 & 2014 & 2013 & 2014 & 2013 & 2014 \\
\hline Faba bean $(\mathrm{A} 1)$ & 250.91 & 249.91 & 140.08 & 139.25 & 20.45 & 20.24 & 47.85 & 47.75 & 31.72 & 31.57 & 552.50 & 549.80 \\
\hline Sugar beet(A2) & 246.66 & 246.25 & 135.41 & 135.16 & 19.76 & 19.16 & 43.35 & 43.25 & 30.44 & 30.33 & 535.50 & 537.60 \\
\hline Wheat(A3) & 225 & 224.33 & 122.75 & 121.75 & 19.25 & 19.08 & 41.62 & 41.56 & 29.25 & 29.16 & 501.50 & 496.80 \\
\hline F-test5\% & ${ }^{*}$ & ㄴ. & * & . & 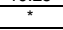 & * & ${ }^{*}$ & ${ }^{*}$ & ${ }^{20.20}$ & $*$ & * & $*$ \\
\hline LSD5\% & 8.42 & 9.68 & 8.45 & 7.67 & 0.435 & 0.343 & 0.896 & 1.30 & 0.676 & 0.694 & 24.25 & 19.70 \\
\hline $\mathrm{B} 1(60 \mathrm{~kg} \mathrm{kgN} / \mathrm{fed})$ & 217.44 & 216.32 & 119.13 & 118.48 & 17.644 & 17.54 & 36.65 & 36.57 & 27.83 & 27.7 & 426.0 & 425.11 \\
\hline B2(75kg N/fed.) & 234.33 & 234.15 & 127.22 & 125.32 & 18.95 & 18.81 & 43.76 & 43.68 & 29.19 & 29.09 & 504.0 & 504.0 \\
\hline B3(90kg N/fed.) & 250.53 & 249.68 & 138.88 & 138.74 & 20.78 & 20.62 & 47.69 & 47.58 & 31.61 & 31.49 & 585.33 & 585.33 \\
\hline B4(105 kgN/fed.) & 261.12 & 260.49 & 145.77 & 145.66 & 22.10 & 21.80 & 48.98 & 48.89 & 33.14 & 33.14 & 604.0 & 598.0 \\
\hline F-test $5 \%$ & * & * & * & * & * & * & * & * & * & * & * & * \\
\hline LSD $5 \%$ & 7.57 & 5.59 & 8.32 & 7.18 & 0.27 & 0.25 & 2.09 & 2.18 & 0.54 & 0.53 & 50.70 & 52.58 \\
\hline $\mathrm{A} \times \mathrm{B}$ & NS & NS & NS & NS & NS & NS & NS & NS & NS & NS & NS & NS \\
\hline
\end{tabular}

Whereas :Faba been(A1),SUGAR BEET(a2) AND Wheat(A3) $\mathrm{B} 1(60 \mathrm{kgN} / \mathrm{fed}),. \mathrm{B} 2(75 \mathrm{kgN}), \mathrm{B} 3(90 \mathrm{kgN})$ andB4(105kgN) NS indicate not significant.

* indicate significant at $5 \%$ level.

Table (7) Means weight of grain /ear, leaf area index and grain yield/fed for maize as affected by different preceding crops and $\mathrm{N}$ levels during 2013 and 2014 seasons

\begin{tabular}{|c|c|c|c|c|c|c|}
\hline \multirow[t]{2}{*}{ Treat } & \multicolumn{2}{|c|}{ W.grain/ear (g) } & \multicolumn{2}{|c|}{ Leaf area index (LAI) } & \multicolumn{2}{|c|}{ Grainyield (Ardab/fed. ) } \\
\hline & First year & Sec Year & First year & Sec Year & First year & Sec Year \\
\hline A1 & 174.35 & 174.29 & 5.21 & 5.18 & 22.98 & 22.87 \\
\hline A2 & 158.38 & 158.26 & 4.95 & 4.85 & 20.88 & 20.76 \\
\hline A3 & 144.83 & 144.39 & 3.94 & 3.59 & 19.11 & 18.95 \\
\hline F-test5\% & * & * & * & * & * & * \\
\hline LSD5\% & 10.58 & 7.62 & 0.08 & 0.23 & 3.06 & 2.08 \\
\hline B1 & 128.19 & 128.09 & 3.07 & 3.04 & 16.99 & 16.91 \\
\hline B2 & 146.55 & 146.53 & 3.95 & 3.89 & 19.38 & 19.23 \\
\hline B3 & 177.84 & 177.72 & 5.48 & 5.35 & 23.39 & 23.22 \\
\hline B4 & 184.17 & 183.59 & 5.99 & 5.89 & 24.22 & 24.09 \\
\hline F-test5\% & * & * & * & * & * & * \\
\hline LSD5\% & 13.77 & 10.96 & 0.301 & 0.31 & 2.31 & 2.27 \\
\hline AXB & NS & NS & NS & NS & NS & NS \\
\hline
\end{tabular}

Whereas :Faba been(A1),SUGAR BEET(a2) AND Wheat(A3)

$\mathrm{B} 1(60 \mathrm{kgN} / \mathrm{fed}$.),B2(75kgN),B3(90kgN)andB4(105kgN)

NS indicate not significant.

*indicate significant at $5 \%$ le 
Table 8: The effects of preceding winter crops and $N$ fertilization rate on available macronutrients in the two seasons(2013 and 2014)

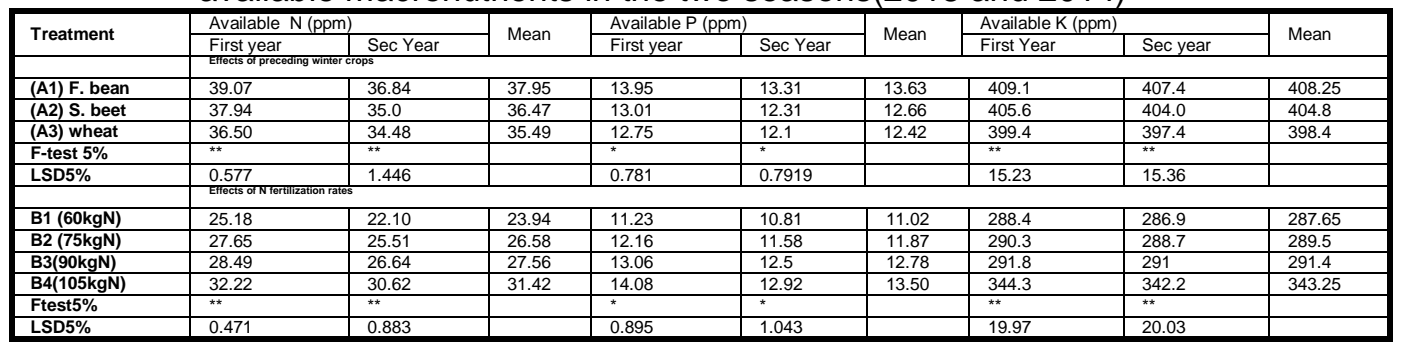

Whereas :Faba been(A1),SUGAR BEET(a2) AND Wheat(A3)

$\mathrm{B} 1(60 \mathrm{kgN} / \mathrm{fed}$.),B2(75kgN),B3(90kgN)andB4(105kgN)

NS indicate not significant.

* indicate significant at $5 \%$ level.

Table 9: Effect of interaction between preceding winter crops and $\mathrm{N}$ fertilization rates on available macronutrients

\begin{tabular}{|c|c|c|c|c|c|c|c|c|c|c|}
\hline \multirow{2}{*}{\multicolumn{2}{|c|}{ Treatment }} & \multicolumn{2}{|c|}{ Available N (ppm) } & \multirow{2}{*}{ Mean } & \multicolumn{2}{|c|}{ Available P (ppm) } & \multirow{2}{*}{ Mean } & \multicolumn{2}{|c|}{ Available K (ppm) } & \multirow{2}{*}{ Mean } \\
\hline & & First year & Sec Year & & First year & Sec Year & & First year & Sec Year & \\
\hline \multirow{4}{*}{ A1 } & B1 & 34.88 & 33.2 & 34.04 & 12.54 & 11.60 & 12.07 & 349.4 & 347.7 & 348.6 \\
\hline & B2 & 35.30 & 33.56 & 34.43 & 12.86 & 11.68 & 12.27 & 402.9 & 400.9 & 401.9 \\
\hline & B3 & 36.87 & 34.67 & 35.77 & 12.98 & 11.71 & 12.35 & 407.4 & 405.6 & 406.5 \\
\hline & B4 & 38.48 & 36.59 & 37.54 & 13.01 & 12.59 & 12.80 & 407.5 & 406.4 & 407 \\
\hline \multirow{4}{*}{ A2 } & B1 & 33.00 & 30.48 & 31.74 & 11.30 & 10.75 & 11.03 & 332.0 & 330.8 & 331.4 \\
\hline & B2 & 33.03 & 30.56 & 31.80 & 12.09 & 11.48 & 11.79 & 334.1 & 332.2 & 333.2 \\
\hline & B3 & 34.24 & 31.34 & 32.79 & 12.10 & 11.58 & 11.84 & 347.8 & 346.5 & 347.2 \\
\hline & B4 & 34.57 & 31.66 & 33.12 & 12.23 & 11.60 & 11.92 & 348.2 & 346.6 & 347.4 \\
\hline \multirow{4}{*}{ A3 } & B1 & 30.62 & 28.49 & 29.56 & 10.62 & 10.27 & 10.45 & 327.7 & 326.1 & 326.9 \\
\hline & B2 & 30.94 & 29.05 & 30.00 & 10.79 & 10.30 & 10.55 & 328.3 & 326.3 & 327.3 \\
\hline & B3 & 31.35 & 29.08 & 30.22 & 10.85 & 10.49 & 10.67 & 329.8 & 328.2 & 329 \\
\hline & B4 & 31.73 & 29.98 & 30.86 & 11.12 & 10.66 & 10.89 & 331.8 & 330.6 & 331.2 \\
\hline \multicolumn{2}{|c|}{ Ftest 5\% } & ** & ** & & NS & NS & & ${ }^{*}$ & ${ }^{*}$ & \\
\hline \multicolumn{2}{|c|}{ LSD 5\% } & 1.125 & 2.819 & & 1.522 & 1.5435 & & 29.68 & 29.94 & \\
\hline
\end{tabular}

Whereas :Faba been(A1),SUGAR BEET(a2) AND Wheat(A3)

$\mathrm{B} 1(60 \mathrm{kgN} / \mathrm{fed}$.),B2(75kgN),B3(90kgN)andB4(105kgN)

NS indicate not significant.

* indicate significant at $5 \%$ level.

\section{REFERENCES}

Abd-El-Samie, F.S., 1994. Growth and yield of maize as affected by $\mathbf{N}$ levels and preceding winter crops Annals of Agricultural Science, 39: 623-631

Abou-keriasha M.A and N. M.A.Eissa(2014)Mineral Nitrogen fertilizer and compost effect on wheat and maize yield in crop sequences including hntercropping legumes Egypt J.Agron. ,36(2):147-163.

Ali.W, A. J, A. Hassan;A. Abbas;A.Hussain;M. Ali;S. A. Zuhair and A. Hussain(2015).Residual effect of preceding legumes and nitrogen levels on subsequent maize . Inter. J. of Agr. and Agric.Res. 7( 1) 78-85.

Armstrong, E.L, J.S. Pate and M.J. Unkovich, 1994. Nitrogen balance of field pea crops in South Western Australia, Studied using the $15 \mathrm{~N}$ natural abundance technique. Aust. Australian J. Plant Physiol. 21: 533-549. 
Arif M, MT Jan , MJ Khan , M Saeed ,I Munir ,H Ziaudin Akbar and MZ Shahenshah Khan . 2011. Effect of cropping system and residue management on maize. Pakistan journal of botany 43, 915-920.

Avcı, E.D., E.Ü. Deveci and H. Kumbur, 2005. Çevre kirliliği ve kontrolünde ekolojik tarımın

Balasbramaniyan P and SP Palaniappan . 2001. Principles and Practices of Agronomy: Integrated Farming System. Agrobios publishers. 486-489..

Berenguer, P., F. Santiveri, J. Boixadera and J. Lloveras, 2009. Nitrogen fertilization of irrigated maize under Mediterranean conditions, European Journal of Agronomy, 30:163-171.

Brockhaus,V.L.(1962).ABCderLandwirtschaftipartr1,2nded.VEB,Brockh ausVeriag,Leipzig,Germany,P:488-489.

Cakir, R., 2004. Effect of water stress at different development stages on vegetative and reproductive growth of corn. Field Crop Research. 89 (1): 1-16

Calderon, A., 2000. Primeros de la aplicacion de alpeorujo en un cultivo de arroz (Oriza sativa L.). Proyecto Fin de Carrera, EUITA, Universidad de Sevilla.

Cesurer, L., 1995. Kahramanmaraş Koşullarında Ekim Zamanı ve Ekim Sıklığının Şeker Mısırında Taze Koçan Verimine ve Diğer Bazı Tarımsal Karakterlere Etkisi. Ç.Ü. Fen Bil. Enst. Tarla Bitkileri Anabilim Dalı, Doktora Tezi, 205s, Adana.

Chaudhry, F. M. (1994). Kharif cereal crops. In E. Bashir \& R. Bantel (Eds), Crop production. NBF, Islamabad

El-Sodany,M.El-D. And A.M.Abou-Elela,2010.Effect of preceding winter crops, relay cropping, intercropping system and nitrogen fertilizer rates on some soil physical,hydrophysical and chemical properties.J.of Soil Science and Agricultural Engineering 1(3):273-298.

Farghly.B.S.(2001).Effect of the preceding winter crop and nitrogen fertilization on yield and yield components of maize and sunflower.Egypt J.Agric.Res.79(4):1423-1437.

F.A.O., 2011. Food and Agriculture Organisation Statistics, FAOSTAT. www.fao.org/faostat

Gomez, K.A. and A. Gomez. 1984. Statistical Procedures of Agricultural Research. John Wiley \& Sons, New York, 2nd ed., 680p.

Gandner,F.A., R.B. Pearce and R.L.Mitchell,1985.Physiolgy of crop plants.lowa State Univ.Press,Ames.Lowa,U.S.AHaque, M. M., Hamid, A., \& Bhuiyan, N. I. (2001). Nutrient uptake and productivity as affected by nitrogen and potassium application levels in maize/sweet potato intercropping system". Korean J. Crop Sci., 46(1), 1-5.

Khalil,H.E.,Al. Nawar ,AM Abou-Elea,EM Ismail,.and M.E. Elsodany,2011.Resspons of maize to $\mathrm{N}$ fertilization following sunflower and preceding winter crops.Alex.J.Agric.Res.56(2),11-19. 
Kamran A., S. K. Khalil1, F. Khan2, S. Abdul Qahar1, M. Sharif and Muhammad Zamin (2014). Phenology, Yield and Yield Components of Maize as Affected by Humic Acid and Nitrogen . J. of Agric. Science; 6 ( 7) 286-293.

Khaliq, T. A. S. N. E. E. M.,TARI Mahmood, JAV Kamal and AM IR Masood, (2004). Effectiveness of farmyard manure, poultry manure and nitrogen for corn (Zea mays L.) productivity. Int. $J$ Agric. Biol, 2, 260-263.

Khan, N.W., N.K. ljaz, and A. Khan, 2012. Integration of Nitrogen Fertilizer And Herbicides For Efficient Weed Management In Maize Crop. Sarhad J. Agric., 28(3).

Muhammad JA and K Khan Saeed, 2005. Grain legume effect soil nitrogen, grain yield and nitrogen nutrition of wheat. crop. J. of Crop Sciences 37, 734-739

Nawar,A.I.2004.Nitrogen requirements for maize cultivars after different winter crops.J.Adv.Agric.Res.9:607-622(FAC Agric.,Saba Basha), Egypt.

Ogola JBO,TRWheeler and PM Haris, 2002. Effect of nitrogen and irrigation on water use of maize crops. Field Crops Res.78, 105-117.

Radford, P.J., 1967. Growth analysis formulae - their use and abuse. Crop Science, Madison, 7: 171-175,

Rhoades, J.D., A.L. Page, D.R. Keeney, D.E. Baker, R.H. Miller and Jr. Roscoe Ellis, 1982. Methods of

Rizivi,J.H. ans V.Rizivi,1992.AllelopathyExploitation of Allelochemicals in Improving after winter crop Producctivity.P456457.Chapman and Hail,U.S.A

Singh, R. P. (1985). Prospects and problems of $N$ and $P$ top dressing in wheat. Paper presented at 24th workshop. All India Wheat Research Workers, held at G.B. Pantnagar Univ. Agril. Tech.

Waller R.A.,and D.B. Duncan (1969). A bays rule for the symmetric multiple comparison problem. Am. Stat. Assoc. J., 1485-1504.

Wallach, D. (1995). Empirical Bays optimal fertilizer decision. J. Appl. Stat., (22):507-516

Wasim, A., J. Amanullah, H Akhtar, A Aqleem, H. Altaf, Murtaza Ali, Syed Ali Z.and HAshraf,2015. Residual effect of preceding legumes and nitrogen levels on subsequent maize . Inter. J. Agric. and Agri. Res. 7, (1) p. 78-85.

Wienhold, B. J., T.P. Trooien, and G.A. Reichman, (1995). Yield and nitrogen use efficiency of irrigated corn in the northern Great Plains. Agron. J., 87, 842-846.

Zamin. M.(2014). Phenology, Yield and Yield Components of Maize as Affected byHumic Acid and Nitrogen. Journal of Agri. Sci.; . 6, (7) 286-293 


$$
\text { الملخص العربى }
$$

تأثير المحصول السابق ومعدل التسميد الازوتي على محصول الحبوب ومكوناتة احمد محمد شيحه , محمد خالد حمدني ,عبد العزيز محمود ابوالعلا وناصر إبراهيم عبد القادر

قسم بحوث التكثيف المحصولي- معه بحوث المحاصيل الحقلية- مركز البحوث الزراعية_الجيزة -

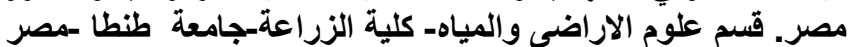

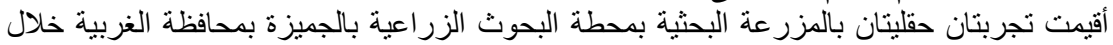

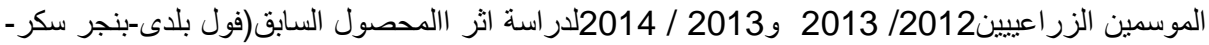

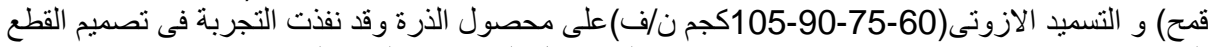

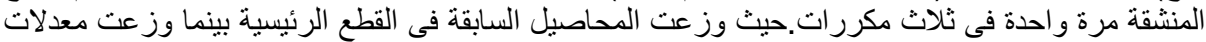
التسميد الازوتى في القطع الثقية

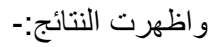

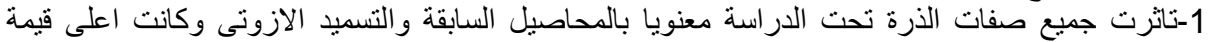

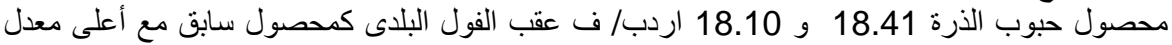

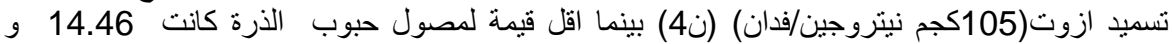

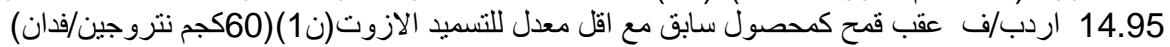

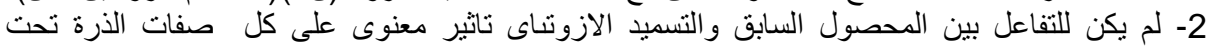

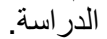

3- اتضح من الدراسة بحساب عائد الفدان بوحدات الحبوب تفوق محصول الذرة عب بنجر سكرعن المحاصيل السابقة الاخرى الإنه

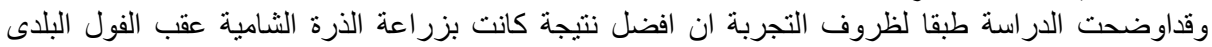

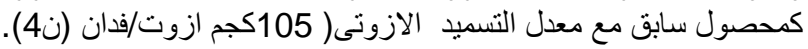

